\section{Average Daily Temperature Effects on Paclobutrazol Efficacy of Four Floriculture Crops}

\author{
Kristin L. Getter ${ }^{1}$
}

AdDitionAl INDEX wORDs. geranium, petunia, marigold, pineapple mint, PGR, plant growth regulator, plant growth retardant

SuMMARY. The effects of paclobutrazol (PBZ), a plant growth retardant, and average daily temperature (ADT) on geranium (Pelargonium $\times$ bortorum), petunia (Petunia $\times$ bybrida), marigold (Tagetes evecta), and pineapple mint (Mentba suaveolens) were quantified. Treatments consisted of four PBZ spray concentrations $(0,15,30$, or $45 \mathrm{ppm}$ ) and three ADTs (constant day and night greenhouse temperatures set to 16,22 , or $28{ }^{\circ} \mathrm{C}$ ). The effectiveness of $\mathrm{PBZ}$ was dependent on species. Greenhouse ADT was significant for all species for both growth index (GI) and dry weight (DW). Whether the GI or DW was impacted by the interaction between ADT and PBZ levels were also species dependent. As ADT increased, the trialed levels of PBZ were less effective. Three species (all but petunia) had a significant ADT and PBZ interaction for DW. The 0 ppm PBZ treatment for geranium exhibited a larger DW at $28^{\circ} \mathrm{C}$ compared with $16^{\circ} \mathrm{C}$, whereas the 30 and $45 \mathrm{ppm}$ PBZ treatments each had smaller DWs at $28{ }^{\circ} \mathrm{C}$ than at $16^{\circ} \mathrm{C}$. However, marigold and pineapple mint generally had larger DWs at higher ADTs than lower ADTs within a PBZ treatment.

$\mathrm{P}$ lant growth regulators are commonly used during greenhouse ornamental plant production (Latimer and Whipker, 2012; Whipker, 2015) and plant growth retardants (PGRs) are the most common type used (Dole and Wilkins, 2005). Producers use PGRs to inhibit internode extension that results in shorter plants with thicker stems and leaves, as well as leaves that may exhibit a darker green color (Latimer and Whipker, 2012). These smaller, sturdier plants allow growers to use bench space more efficiently and help plants to endure shipping and retail handling. In addition, there are other potential benefits of PGRs including improved plant water-use efficiency (Ahmad et al., 2014; Jungklang and Saengnil, 2012) and disease suppression (Hill and Latimer, 2004).

In the U.S. floriculture industry, the PGR most extensively used is PBZ (Whipker, 2015). This may be because PBZ has a low likelihood for phytotoxicity, can be applied in many different ways (sprayed, drenched, or dipped), and is generally effective on a wide range of crops (Ahmad et al., 2014; Currey and Erwin, 2012; Miller

Department of Horticulture, Michigan State University, 1066 Bogue Street, East Lansing, MI 48824

I thank the Metro Detroit Flower Growers Association and the West Michigan Greenhouse Association for funding this work.

${ }^{1}$ Corresponding author. E-mail: getterk@msu.edu. and Armitage, 2002). Typical foliar spray concentrations for $\mathrm{PBZ}$ range from 15 to $30 \mathrm{ppm}$ for bedding plants, with lower and higher doses used for northern climates and southern climates, respectively (Whipker, 2015). Most PGR research has investigated controlling plant size and very few studies have reported other factors that may impact the effectiveness of a PGR treatment.

Plant height and growth rate are affected by many environmental factors. Stem elongation is affected by the difference between day and night temperatures (DIF) for many floriculture species (Erwin and Heins, 1995). Light quality and quantity, as well as photoperiod, can interact with DIF to affect plant internode length (Myster and Moe, 1995). The ADT impacts the rate of plant development, with faster rates at higher compared with lower temperatures, assuming the temperature is within the tolerable range for the species and other factors (light, nutrition, etc.) are not limiting (Dole and Wilkins, 2005; Ministry of
Agriculture, Food and Rural Affairs, $2014)$. Research on poinsettia (Euphorbia pulcherrima) sprayed with uniconazole (a PGR in the same group of chemicals as PBZ) demonstrated that bract diameter and shoot length were greater under warmer greenhouse regimes compared with cooler ones (Barrett, 2001). The objective of this study was to build on previous research to evaluate the relative efficacy of three PBZ concentrations on four ornamental annual species grown at three greenhouse ADTs.

\section{Materials and methods}

Seeds of four species were sown in 128-plug trays ('Pinto Premium Deep Red' geranium, 'Wave Purple Improved' petunia, 'Inca II Yellow' marigold) or 36-strip trays ('Pineapple' pineapple mint) by a commercial greenhouse (C. Raker \& Sons, Litchfield, MI) in a substrate consisting of peat and perlite. These varieties were selected by the plug producer based on their commonality and commercial availability. Four to 6 weeks after germination, plugs were received at Michigan State University (East Lansing) on 10 Nov. 2014.

Plugs were transplanted into 4 -inch pots on 10 Nov. 2014 and were kept in a constant $20^{\circ} \mathrm{C}$ greenhouse until roots reached the edge of pots ( $9 \mathrm{~d}$ after transplanting). Treatments consisted of four PBZ (Fine Americas, Walnut Creek, CA) spray concentrations [0 (control) 15,30 , or $45 \mathrm{ppm}$ ] and three ADTs (constant day and night greenhouse temperatures set to 16,22 , or $28^{\circ} \mathrm{C}$ ). Ten plants of each species were assigned to each treatment, resulting in 480 plants in total $(4 \mathrm{PBZ}$ treatments $\times 3$ ADTs $\times 4$ species $\times 10$ plants). On 19 Nov. 2014, the treatment foliar PBZ spray was applied (without a surfactant) with a 4-pt handheld sprayer (Flo-Master; Root-Lowell Manufacturing Co., Lowell, MI) at $2 \mathrm{qt} / 100 \mathrm{ft}^{2}$ and plants were moved to their ADT treatment greenhouse.

\begin{tabular}{llll}
\hline $\begin{array}{l}\text { Units } \\
\begin{array}{l}\text { To convert U.S. to SI, } \\
\text { multiply by }\end{array}\end{array}$ & U.S. unit & SI unit & $\begin{array}{l}\text { To convert SI to U.S., } \\
\text { multiply by }\end{array}$ \\
\hline 2.54 & inch $(\mathrm{es})$ & $\mathrm{cm}$ & 0.3937 \\
1 & $\mathrm{ppm}$ & $\mathrm{mg} \cdot \mathrm{L}^{-1}$ & 1 \\
0.4732 & $\mathrm{pt}$ & $\mathrm{L}$ & 2.1134 \\
0.1019 & $\mathrm{qt} / 100 \mathrm{ft}^{2}$ & $\mathrm{~L} \cdot \mathrm{m}^{-2}$ & 9.8170 \\
$\left({ }^{\circ} \mathrm{F}-32\right) \div 1.8$ & ${ }^{\circ} \mathrm{F}$ & ${ }^{\circ} \mathrm{C}$ & $\left({ }^{\circ} \mathrm{C} \times 1.8\right)+32$
\end{tabular}


The greenhouse temperature set points were maintained by a computer that automatically controlled heating and passive and active ventilation. The air temperature was measured, independent from the greenhouse environmental control system, at plant height on each greenhouse bench using type E thermocouples (TT-E-40; Omega Engineering, Stamford, CT) placed in aspirated tubes connected to a data logger (CR10; Campbell Scientific, Logan, UT) and data were collected every $10 \mathrm{~s}$ and hourly means were computed and recorded on a computer.

Weekly plant measurements consisted of several quantitative measures. Plant height was measured in centimeters from the top of the soil to the tallest point of the plant. Plant width 1 was measured as the width in centimeters at the widest portion of the plant and plant width 2 was the width perpendicular to plant width $\mathrm{l}$ in centimeters. A GI was calculated as [ (plant height + plant width $1+$ plant width 2)/3] to represent the size of the plant. At the end of the study, shoot DW was determined by harvesting, drying (at $70{ }^{\circ} \mathrm{C}$ for $7 \mathrm{~d}$ ), and weighing the aboveground portion of all plants. Initial plant measurements occurred on 19 Nov. 2014 and weekly measurements were made thereafter until all plants were in flower [saleable (15 Dec. 2014 for petunia and pineapple mint, 22 Dec. 2014 for marigold and geranium)]. All plants were fertilized at each watering with reverse osmosis water containing nutrients [in $\mathrm{mg} \cdot \mathrm{L}^{-1}(125$ nitrogen, 12 phosphorous, 100 potassium, 65 calcium, 12 magnesium, 1.0 iron and copper, 0.5 manganese and zinc, and 0.1 molybdenum)]. Each pot was individually hand watered as needed. A 16-h photoperiod $(0600$ to $2200 \mathrm{HR}$ ) was maintained in each greenhouse with a combination of sunlight and high-pressure sodium (HPS) lamps. In addition, plants received supplemental light of $\approx 90 \mu \mathrm{mol} \cdot \mathrm{m}^{-2} \cdot \mathrm{s}^{-1}$ from HPS lamps when the ambient photosynthetic photon flux (PPF) was $<371 \mu \mathrm{mol} \cdot \mathrm{m}^{-2} \cdot \mathrm{s}^{-1}$ and ceased when the $P P F$ was $>425 \mu \mathrm{mol} \cdot \mathrm{m}^{-2} \cdot \mathrm{s}^{-1}$.

Data for each species were analyzed separately as a two-way factorial arrangement on a complete randomized design with ADT and PBZ spray with 10 replications (plants per treatment). Data were analyzed using
SAS (version 9.3; SAS Institute, Cary, NC) PROC GLM and paired comparisons were performed using Tukey's honestly significant test with $P=0.05$ as a maximum value of significance.

\section{Results}

During the study, the greenhouses set to an ADT of 16, 22, and $28{ }^{\circ} \mathrm{C}$ averaged $16.2,22.4$, and $27.2^{\circ} \mathrm{C}$, respectively (data not shown). The GI analysis of variance (ANOVA) table is shown by species for each week of the study in Table 1 . Week number 0 represented the day PBZ was sprayed (19 Nov. 2014), and week number 1 , 2,3 , and 4 represented each subsequent week of the study $(1,8,15$, and 22 Dec. 2014, respectively). For all species, the ANOVA model and ADT were significant across 3 or 4 weeks of the study, with one exception (geranium at week number 1 ). The significance of the PBZ treatment and its interaction with ADT depended on species. The plant DW ANOVA is shown in Table 2 at the conclusion of the study (week number 4 for geranium and marigold and week number 3 for petunia and pineapple mint). The model was the only factor that was significant across all species. The three other factor's significance (ADT, PBZ treatment, and their interaction) depended on the species.

Geranium. ADT had a significant effect on geranium GI for all but the first week of the study and PBZ treatments were significant for all 4 weeks of the study $(P \leq 0.05)$ as was their interaction $[P \leq 0.10$ (Table 1$)]$. At the conclusion of the study (week number 4), within each ADT, PBZ produced smaller plants than those not treated with PBZ (Table 3). In addition, higher levels of PBZ produced smaller GIs than lower PBZ levels at lower ADTs $\left(16\right.$ and $\left.22^{\circ} \mathrm{C}\right)$, but all concentrations of PBZ were equally effective at $28{ }^{\circ} \mathrm{C}$. The plants treated with $\mathrm{PBZ}$ were up to $30 \%$ $(4.68 \mathrm{~cm})$ smaller than their respective control at the lower ADTs (16 and $22^{\circ} \mathrm{C}$ ), whereas the plants at a higher ADT $\left(28{ }^{\circ} \mathrm{C}\right)$ were only up to $14 \%$ $(2.29 \mathrm{~cm})$ smaller than their control.

The geranium DW ANOVA model was significant at the end of the study (week number 4), as was $\mathrm{PBZ}$, and the interaction between PBZ and ADT (Table 2). However, ADT was not significant. The interaction between ADT and PBZ can be seen in mean plant DWs (Table 4). Within the lower ADTs $\left(16\right.$ and $\left.22^{\circ} \mathrm{C}\right)$, plants treated with PBZ exhibited less DW than their respective controls, whereas plants at a higher ADT $\left(28{ }^{\circ} \mathrm{C}\right)$ weighed the same as the control.

Marigold. The GI ANOVA model for marigold was significant, as was ADT, but not the PBZ treatment nor their interaction during all 4 weeks of the study (Table 1 ). The latter is reflected in the marigold mean GI where the GIs are the same for each PBZ treatment within an ADT (Table 3). However, for DWs, marigold's ANOVA had a significant model and all three terms (ADT, PBZ treatment, and their interaction) were significant at the end of the study [week 4 (Table 2)]. Within each PBZ treatment, plants at $16^{\circ} \mathrm{C}$ had smaller DWs than those at $28^{\circ} \mathrm{C}$ (Table 4). The interaction between ADT and PBZ is demonstrated in that for lower ADTs $\left(16\right.$ and $\left.22^{\circ} \mathrm{C}\right)$, all plants treated with PBZ had the same DW as their respective control. However, at $28{ }^{\circ} \mathrm{C}$ plants treated with 30 or $45 \mathrm{ppm} \mathrm{PBZ} \mathrm{concentra-}$ tions were larger than the control plants.

Petunia. Similar as marigold, petunia's GI ANOVA model and ADT were both significant for all 3 weeks of the study and the PBZ treatment and its interaction with ADT were not significant for the duration of the study (Table 1 ). At the conclusion of the study (week 3 ), GIs for each PBZ treatment were the same as their control within an ADT (Table 3). Unlike marigold, petunia's DW ANOVA was significant for all but one term [the interaction between ADT and PBZ (Table 2)]. For 22 and $28{ }^{\circ} \mathrm{C}$, DWs were the same as the control within each ADT and between PBZ treatments (Table 4). For $16^{\circ} \mathrm{C}$, only the $45 \mathrm{ppm}$ PBZ concentration had smaller DWs than the control. Within each PBZ treatment, all ADTs produced the same DWs except for the 45-ppm PBZ level where lower ADTs had lower DWs than higher ADTs.

Pineapple mint. Pineapple mint had the same trends for GI as petunia (Tables 1 and 3 ). Pineapple mint's DW ANOVA model, as well as ADT and the PBZ and ADT interaction were all significant at the conclusion of the study (week 3), but not PBZ 
Table 1. Analysis of variance probability values for plant growth index defined as [(plant height + plant width $1+$ plant width 2)/3] shown by species and week number, modeled against average daily temperature $(\mathrm{ADT})\left[16,22\right.$, or $^{\circ} 8^{\circ} \mathrm{C}(60.8$, 71.6 , or $\left.\left.82.4^{\circ} \mathrm{F}\right)\right]$ and paclobutrazol $(\mathrm{PBZ})$ spray concentration $\left[0,15,30\right.$, or $\left.45 \mathrm{ppm}\left(\mathrm{mg} \cdot \mathrm{L}^{-1}\right)\right]$.

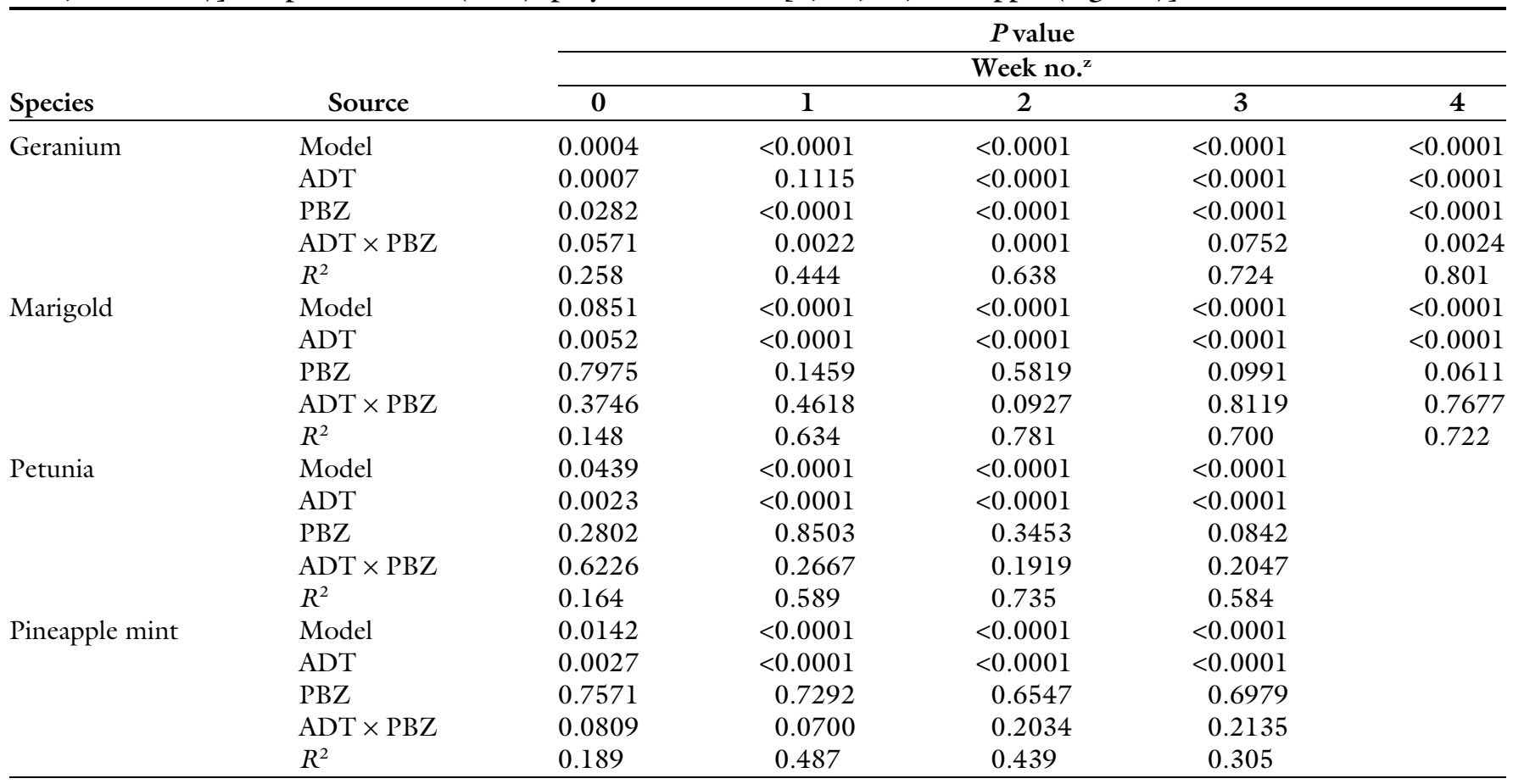

${ }^{\mathrm{z}}$ Week number 0 measurements were the day of the PBZ spray (19 Nov. 2014). Week numbers $1,2,3$, and 4 were 1, 8, 15, and 22 Dec. 2014, respectively.

Table 2. Analysis of variance probability values for plant dry weight at week 3 (15 Dec. 2014 for pineapple mint and petunia species) or 4 ( 22 Dec. 2014 for geranium and marigold) shown by species modeled against average daily temperature (ADT) $\left[16,22\right.$, or $28^{\circ} \mathrm{C}\left(60.8,71.6\right.$, or $\left.\left.82.4^{\circ} \mathrm{F}\right)\right]$ and paclobutrazol $(\mathrm{PBZ})$ spray concentration $\left[0,15,30, \mathrm{or} 45 \mathrm{ppm}\left(\mathrm{mg} \cdot \mathrm{L}^{-1}\right)\right]$.

\begin{tabular}{|c|c|c|c|c|c|c|c|}
\hline Species & Source & df & Sum of squares & Mean square & F value & $P>\mathrm{F}$ & $R^{2}$ \\
\hline \multirow[t]{5}{*}{ Geranium } & Model & 11 & 17.485 & 1.589 & 14.46 & $<0.0001$ & 0.598 \\
\hline & $\mathrm{ADT}$ & 2 & 0.0832 & 0.042 & 0.38 & 0.6857 & \\
\hline & $\mathrm{ADT} \times \mathrm{PBZ}$ & 6 & 5.891 & 0.982 & 8.93 & $<0.0001$ & \\
\hline & Error & 107 & 11.765 & 0.109 & & & \\
\hline & Corrected total & 118 & 29.250 & & & & \\
\hline & PBZ & 3 & 9.554 & 3.184 & 8.39 & $<0.0001$ & \\
\hline & $\mathrm{ADT} \times \mathrm{PBZ}$ & 6 & 7.691 & 1.281 & 3.38 & 0.0044 & \\
\hline & Error & 105 & 39.849 & 0.379 & & & \\
\hline & Corrected total & 116 & 187.651 & & & & \\
\hline \multirow[t]{2}{*}{ Petunia } & Model & 11 & 11.881 & 1.080 & 3.71 & 0.0002 & 0.288 \\
\hline & Corrected total & 112 & 41.262 & & & & \\
\hline \multirow[t]{6}{*}{ Pineapple mint } & Model & 11 & 19.107 & 1.737 & 13.37 & $<0.0001$ & 0.586 \\
\hline & $\mathrm{ADT}$ & 2 & 13.325 & 6.662 & 51.30 & $<0.0001$ & \\
\hline & PBZ & 3 & 0.173 & 0.058 & 0.45 & 0.7210 & \\
\hline & $\mathrm{ADT} \times \mathrm{PBZ}$ & 6 & 4.901 & 0.817 & 6.29 & $<0.0001$ & \\
\hline & Error & 104 & 13.507 & 0.129 & & & \\
\hline & Corrected total & 115 & 32.614 & & & & \\
\hline
\end{tabular}

df = degrees of freedom.

itself (Table 2). Within each ADT, plants treated with PBZ exhibited DWs different from their control for only the 22 and $28^{\circ} \mathrm{C}$ ADT (Table 4 ) and this only for higher PBZ concentrations (30 or $45 \mathrm{ppm})$. Within each
PBZ treatment, the lower ADT $\left(16^{\circ} \mathrm{C}\right)$ produced smaller DWs than $28^{\circ} \mathrm{C}$. 
Table 3. Mean growth index (GI) [(plant height + plant width $1+$ plant width 2$) / 3]$ by species, average daily temperature [ADT $\left(16,22\right.$, or $\left.\left.28^{\circ} \mathrm{C}\right)\right]$ and paclobutrazol spray concentration $[\mathrm{PBZ}(0,15,30$, or $45 \mathrm{ppm})]$ at the conclusion of the study [week 3 (15 Dec. 2014) for pineapple mint and petunia species, week 4 (22 Dec. 2014) for geranium and marigold].

\begin{tabular}{|c|c|c|c|c|}
\hline \multirow[b]{3}{*}{ Species } & \multirow[b]{3}{*}{ PBZ treatment $(\mathrm{ppm})^{\mathrm{z}}$} & \multicolumn{3}{|c|}{$\mathrm{GI}[\operatorname{mean}(\mathrm{sE})(\mathrm{cm})]^{\mathrm{z}}$} \\
\hline & & \multicolumn{3}{|c|}{$\operatorname{ADT}\left({ }^{\circ} \mathrm{C}\right)^{\mathrm{z}}$} \\
\hline & & 16 & 22 & 28 \\
\hline & 15 & $11.09(0.328) \mathrm{B} \mathrm{b}$ & $13.65(0.457) \mathrm{B}$ a & $14.29(0.310) \mathrm{B} \mathrm{a}$ \\
\hline & 30 & $9.77(0.279) \mathrm{C} \mathrm{c}$ & $11.52(0.314) \mathrm{C} \mathrm{b}$ & $14.06(0.314) \mathrm{B} \mathrm{a}$ \\
\hline & 45 & $9.56(0.209) \mathrm{C} \mathrm{c}$ & $10.91(0.219) \mathrm{C} \mathrm{b}$ & $14.14(0.437) \mathrm{B} \mathrm{a}$ \\
\hline \multirow{2}{*}{ Marigold } & 30 & $21.97(0.665) \mathrm{A} \mathrm{b}$ & $27.71(0.543) \mathrm{A} \mathrm{a}$ & $26.47(0.624) \mathrm{A} \mathrm{a}$ \\
\hline & 45 & $22.09(0.419) \mathrm{A} \mathrm{b}$ & $28.92(0.513) \mathrm{A} \mathrm{a}$ & $28.01(0.522) \mathrm{A} \mathrm{a}$ \\
\hline \multirow[t]{3}{*}{ Petunia } & 0 & $24.95(1.018) \mathrm{A} \mathrm{b}$ & $32.29(0.724) \mathrm{A} \mathrm{a}$ & $29.51(1.751) \mathrm{A} \mathrm{a}$ \\
\hline & 15 & $24.64(0.886) \mathrm{A} \mathrm{b}$ & $31.05(0.581) \mathrm{A} \mathrm{a}$ & $32.32(0.972) \mathrm{A} \mathrm{a}$ \\
\hline & 30 & $24.49(0.725) \mathrm{A} \mathrm{b}$ & $34.82(1.661) \mathrm{A} \mathrm{a}$ & $33.77(1.298) \mathrm{A} \mathrm{a}$ \\
\hline Pineapple mint & 45 & $19.88(0.403) \mathrm{A} \mathrm{b}$ & $21.36(0.659) \mathrm{A} \mathrm{ab}$ & $22.29(0.592) \mathrm{A} \mathrm{a}$ \\
\hline
\end{tabular}

${ }^{\mathrm{z}} 1 \mathrm{ppm}=1 \mathrm{mg} \cdot \mathrm{L}^{-1}, 1 \mathrm{~cm}=0.3937$ inch, $\left(1.8 \times{ }^{\circ} \mathrm{C}\right)+32={ }^{\circ} \mathrm{F}$.

y Uppercase letters in columns represent means separation using Tukey’s honestly significant test $(P \leq 0.05)$ within a species and ADT between PBZ treatments.

'Lowercase letters in rows represent means separation using Tukey's honestly significant test $(P \leq 0.05)$ within a species and PBZ treatment, between ADT regimes.

Table 4. Mean plant dry weight (DW) at the conclusion of the study [week 3 (15 Dec. 2014) for pineapple mint and petunia, week 4 (22 Dec. 2014) for geranium and marigold] by average daily temperature [ADT (16, 22, or $\left.^{\circ} 8^{\circ} \mathrm{C}\right)$ ] and paclobutrazol spray concentration $[\mathrm{PBZ}(0,15,30$, or $45 \mathrm{ppm})]$.

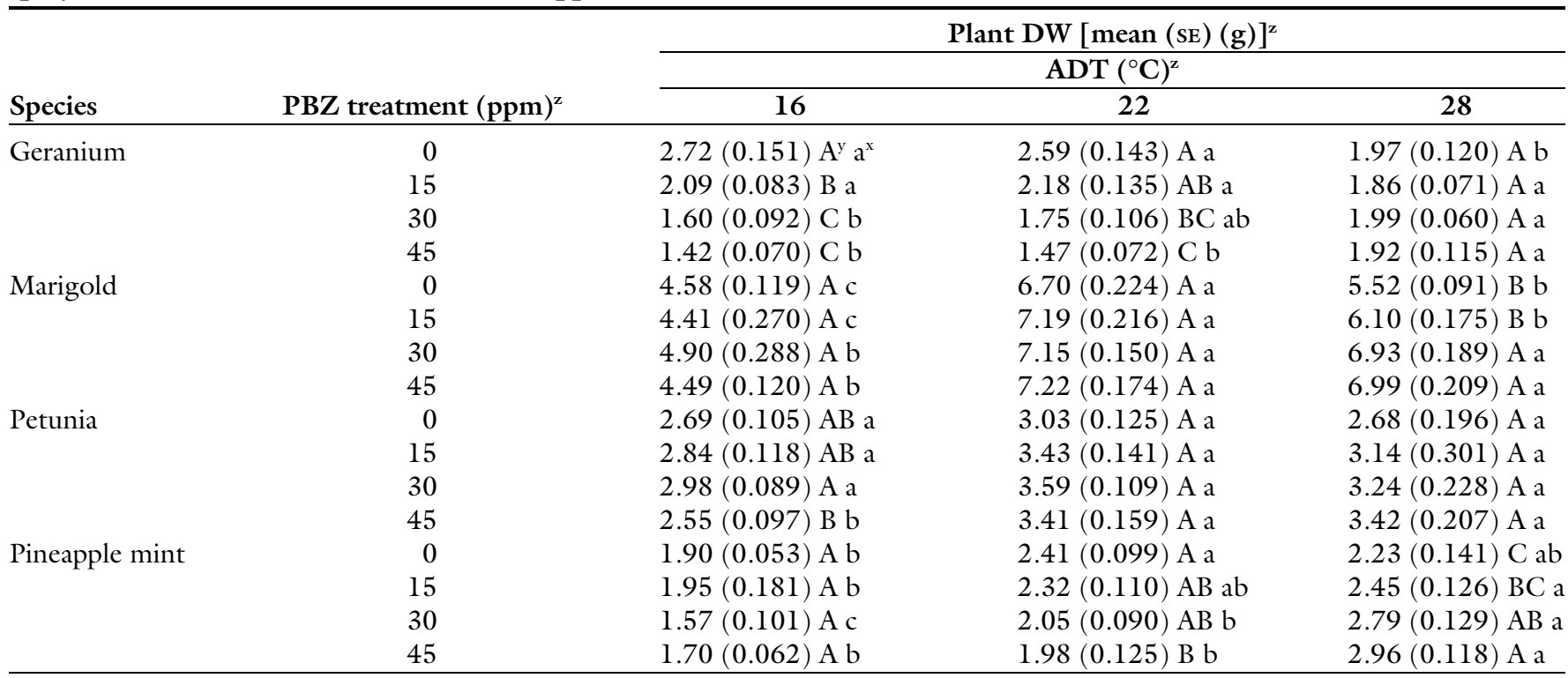

${ }^{\mathrm{z}} 1 \mathrm{ppm}=1 \mathrm{mg} \cdot \mathrm{L}^{-1}, 1 \mathrm{~cm}=0.3937$ inch, $\left(1.8 \times{ }^{\circ} \mathrm{C}\right)+32={ }^{\circ} \mathrm{F}$

y Uppercase letters in columns represent means separation using Tukey's honestly significant test $(P \leq 0.05)$ within a species and ADT between PBZ treatments.

'Lowercase letters in rows represent means separation using Tukey's honestly significant test $(P \leq 0.05)$ within a species and PBZ treatment, between ADT regimes.

\section{Discussion}

In this study, the effectiveness of PBZ was dependent on species. For GI, geranium was the only species that exhibited a PBZ effect (i.e., the PBZ ANOVA term was significant). Had higher concentrations or repeated applications of $\mathrm{PBZ}$ been used [as suggested by Latimer and Whipker (2012)], the more aggressive species (marigold and petunia) may have had a significant PBZ effect.

The use of PBZ resulted in smaller DWs of three species (geranium, marigold, and petunia). These results were consistent with other research that demonstrated PGRs to be species-or even varietydependent (Barrett, 2001; Currey and Erwin, 2012; Hammond et al., 2007; Sprzaczka and Laskowska, 2013). In almost all cases, DW decreased as PBZ increased within an ADT, which is consistent with other recent research as well (Rezazadeh and Harkess, 2015). 
Greenhouse ADT was significant for all species for both GI and DW. This is expected in that as long as the growing temperature is within a species tolerable range, plant growth and time to flowering are faster at higher ADTs compared with lower ADTs (Dole and Wilkins, 2005; Ministry of Agriculture, Food and Rural Affairs, 2014). However, faster production time at higher ADTs may not result in high quality plants as measured by number of flowers, size of flowers, number of branches, and shoot DW (Mattson and Erwin, 2003; Vaid et al., 2014).

Whether the GI or DW was impacted by the interaction between ADT and PBZ levels was also species dependent. Geranium was the only species to have such an interaction for GI. As ADT increased, the trialed levels of PBZ were less effective. Each PBZ treatment on geranium resulted in GIs up to $30 \%(4.68 \mathrm{~cm})$ smaller than their respective control at the lower ADTs ( 16 and $22^{\circ} \mathrm{C}$ ), whereas the higher ADT $\left(28^{\circ} \mathrm{C}\right)$ was only up to $14 \%(2.29 \mathrm{~cm})$ smaller than its control. This is consistent with Barrett's (2001) research, which reported that a similar PGR (uniconazole) at a single concentration had a greater plant height and bract size of poinsettia at higher greenhouse temperatures than at lower greenhouse temperatures. Three species (all but petunia) had a significant ADT and PBZ interaction for DW. Within a PBZ treatment, geranium exhibited smaller or similar DWs at $28{ }^{\circ} \mathrm{C}$ compared with $16{ }^{\circ} \mathrm{C}$, whereas the 30 and 45 ppm PBZ treatments each had larger DWs at $28^{\circ} \mathrm{C}$ than at $16{ }^{\circ} \mathrm{C}$. However, marigold and pineapple mint generally had larger DWs at higher ADTs than lower ADTs within a PBZ treatment. Other research has shown that shoot DW can be diminished by a PGR treatment and the increasing temperatures can increase DW (Latimer, 1991; Miller and Armitage, 2002).

\section{Conclusions}

The effect of ADT on PBZ efficacy of these four floriculture crops was largely dependent on species. Of the species tested here, only geranium was impacted by ADT, PBZ, and their interaction. Growers should use the results of this study to guide their PGR applications. For less aggressive crops (i.e., geranium), the efficacy of PBZ is impacted by ADT. Therefore, growers may need to use higher concentrations of PBZ when growing at higher ADTs. For more aggressive crops, higher concentrations of PBZ may also be needed due to their vigorous growth habit.

One potential reason marigold, petunia, and pineapple mint had fewer effects from PBZ and the interaction between ADT and PBZ is that the concentration of PBZ may not have been high enough. This study used PBZ concentrations ranging from 15 to $45 \mathrm{ppm}$, which encompassed most of the recommended PBZ spray concentration ranges for the four species tested here (Whipker, 2015). However, others have recommended that higher concentrations or repeated or earlier applications of PBZ may be needed for vigorous varieties such as marigold, petunia, and pineapple mint (Latimer and Whipker, 2012). Future research should examine higher concentrations of PBZ for these and other species.

\section{Literature cited}

Ahmad, I., B.E. Whipker, J.M. Dole, and I. McCall. 2014. Paclobutrazol and ancymidol lower water use of potted ornamental plants and plugs. European J. Hort. Sci. 79:318-326.

Barrett, J.E. 2001. Mechanisms of action, p. 32-47. In: M.L. Gaston (ed.). Tips on regulating growth of floriculture crops. Ball Publ., Batavia, IL.

Currey, C.J. and J. Erwin. 2012. Foliar applications of plant growth regulators affect stem elongation and branching of 11 kalanchoe species. HortTechnology 22:338-344.

Dole, J.M. and H.F. Wilkins. 2005. Floriculture principles and species. 2 nd ed. Prentice Hall, Upper Saddle River, NJ.

Erwin, J.E. and R.D. Heins. 1995. Thermomorphogenic responses in stem and leaf development. HortScience 30:940-949.

Hammond, H.E., R.K. Schoellhorn, S.B. Wilson, and J.G. Norcini. 2007. Differing blanketflower cultivar and ecotype responses to plant growth regulators. HortTechnology 17:552-556.

Hill, S. and J.G. Latimer. 2004. Effects of plant growth regulators on the severity of powdery mildew on Pblox paniculata 'Blue Boy' and Rudbeckia hirta 'Indian Summer'. Proc. 31st Annu. Mtg. Plant Growth Regulat. Soc. Amer. p. 22-25.

Jungklang, J. and K. Saengnil. 2012. Effect of paclobutrazol on patumma cv. 'Chiang Mai Pink' under water stress. Songklanakarin J. Sci. Technol. 34:361366.

Latimer, J.G. 1991. Growth retardants affect landscape performance of zinnia, impatiens, and marigold. HortScience 26:557-560.

Latimer, J.G. and B.E. Whipker. 2012. Selecting and using plant growth regulators on floriculture crops. Virginia Polytechnic Inst. State Univ. Ext Publ. 430-102.

Mattson, N.S. and J.E. Erwin. 2003. Temperature affects flower initiation and development rate of impatiens, petunia, and viola. Acta Hort. 624:191-197.

Miller, A. and A.M. Armitage. 2002. Temperature, irradiance, photoperiod, and growth retardants influence greenhouse production of Angelonia angustifolia Benth. Angel mist series. HortScience 37:319-321.

Ministry of Agriculture, Food and Rural Affairs. 2014. Guide to greenhouse floriculture production. Ministry Agr., Food Rural Affairs Publ. 370.

Myster, J. and R. Moe. 1995. Effect of diurnal temperature alternations on plant morphology in some greenhouse crops A mini review. Sci. Hort. 62:205-215.

Rezazadeh, A. and R.L. Harkess. 2015. Effects of pinching, number of cuttings per pot, and plant growth regulators on height control of purple firespike. HortTechnology 25:71-75.

Sprzaczka, I. and H. Laskowska. 2013. Evaluation of flurprimidol efficiency in pot cultivation of forced tulips. Acta Sci. Pol. Hortorum Cultus 12:25-33.

Vaid, T.M., E.S. Runkle, and J.M. Frantz. 2014. Mean daily temperature regulates plant quality attributes of annual ornamental plants. HortScience 49:574-580.

Whipker, B.E. 2015. Plant growth regulators for annuals. Ball Publ., West Chicago, IL. 